\author{
В. В. Петров, А. А. Крючин, С. М. Шаноймо, \\ Є. В. Бемяк, О. Г. Мельник \\ Інститут проблем реєстрації інформації НАН України \\ вул. М. Шпака, 2, 03113 Київ, Україна
}

\title{
Технології створення оптичних носіїв Аля систем довготермінового зберігання даних
}

\begin{abstract}
Визначено переваги систем довготермінового зберігання даних, в яких використовуються носї з оптичним зчитуванням, що виготовлені $з$ високостабільних матеріалів. Показано, що суттєво збільшити строки зберігання даних на оптичних носіях можливо з переходом на використання підкладок з неорганічних матеріалів. Заміна матеріалів фоточутливих шарів оптичних носіїв з одноразовим записом (WORMносіі) не дозволяє в повному обсязі реалізувати потениійні можливості оптичних методів запису із забезпечення довготермінового зберігання даних. Вказано, щзо форма представлення даних на оптичних носіях довготермінового зберігання повинна допускати можливість відтворення даних різними методами.
\end{abstract}

Ключові слова: оптичні носії, довготермінове зберігання інформації, представлення даних, підкладки, високостабільні матеріали, реєструвальні середовища.

\section{Вступ}

Задача збереження інформації є однією з актуальних задач інформаційних технологій, при вирішенні якої необхідно забезпечити надійне та компактне зберігання як уже накопиченої, так і нової інформації. Питання довготермінового зберігання інформації завжди привертало увагу людства і зараз залишається одним із найважливіших завдань архівних установ і бібліотек. Сучасні технології довготермінового зберігання інформації базуються на методі міграції даних, яка при орієнтації на використання жорстких магнітних дисків для довготермінового зберігання інформації передбачає постійний (кожні 4-5 років) перезапис даних на нові носії інформації [1]. Технологія довготермінового зберігання інформації 3 використанням носіїв інформації з малим строком служби і постійним проведенням процесу міграції є високовитратною і не забезпечує високої надійності зберігання даних. Збереження даних у цифровій формі піднімає проблеми принципово

(C) В. В. Петров, А. А. Крючин, С. М. Шанойло, Є. В. Беляк, О. Г. Мельник 
іншої природи, які додаються до проблем збереження традиційних документальних матеріалів. Одна з проблем полягає в тому, що носії інформації для зберігання документів у цифровій формі мають менший термін зберігання даних навіть в ідеальних умовах, такі носії вразливі до катастрофічних втрат записаної інформації. Загрози втрати інформації, яка зберігається на сучасних цифрових носіях, якісно відрізняються від проблем зберігання даних на традиційних носіях. Якість цифрових носіїв за певних умов може швидко погіршуватися, що робить терміни рішень і дій щодо запобігання втратам питанням років, а не десятиліть. Поліпшення стабільності характеристик, ємності, довговічності цифрових носіїв дозволить різко знизити вразливість цифрових матеріалів до впливу зовнішніх факторів і знизити витрати на зберігання даних [2]. Недовіра до можливостей цифрових носіїв забезпечувати високу надійність довготермінового зберігання даних у цифровому вигляді призводить до того, що у багатьох випадках не змінено законодавство, яке передбачає необхідність паралельно з цифровими носіями зберігати в архівах паперові документи, в тому числі й описи документів. При цьому використання цифрових копій документів в архівах, у першу чергу, обумовлено необхідністю вирішення питання виконання пошукових запитів [10]. Відсутність високоємних носіїв з цифровим записом, які мають тривалий гарантований термін зберігання даних, призводить до того, що для архівного зберігання даних широко використовують мікрофільми з аналоговим способом запису. При використанні сучасних матеріалів для їхнього виготовлення і особливих умов зберігання мікрофільмів, вони можуть забезпечувати зберігання даних протягом сотень років $[4,5]$. Таким чином, актуальною задачею є створення ефективної інфраструктури зберігання інформації, яка забезпечує отримання необхідної інформації, гарантує довготермінове та надійне зберігання даних.

\section{Аналіз технологій створення носіїв ААя систем Аовготермінового зберігання Ааних}

Найбільш стійкими до руйнівного впливу часу виявилися ті пам'ятники письмової та образотворчої культури, які були виконані на твердих матеріальних носіях - каменях, металі, кераміці. Саме завдяки цьому до нас дійшли глиняні таблички шумерів (термін зберігання понад 4000 років), розшифровані єгипетські ієрогліфи («Розетський камінь», матеріал - блакитний мармур, термін зберігання понад 2000 років), давньоіндійські письмена (колона в Делі, матеріал - залізо, термін зберігання понад 1600 років). Зберігання інформації на твердих носіях тисячоліттями вважалося самим надійним способом зберегти знання протягом століть [6]. Вибір оптимальної технології зберігання даних може здійснюватися з використанням таких критеріїв: вартість, довговічність і строки міграції даних. Для носіїв інформації усіх типів з різними способами запису спостерігається загальна закономірність - зниження термінів зберігання даних при збільшенні щільності запису (наведені на рисунку) [7].

Головним обмежуючим чинником до визначення числа об'єктів, які необхідно зберігати тривалий час може бути вартість зберігання даних. Дослідники систем довготермінового зберігання інформації відзначають, що вартість органі- 
зації процесу довготермінового зберігання даних є високою та багато в чому визначається вартістю і характеристиками використовуваних носіїв інформації.

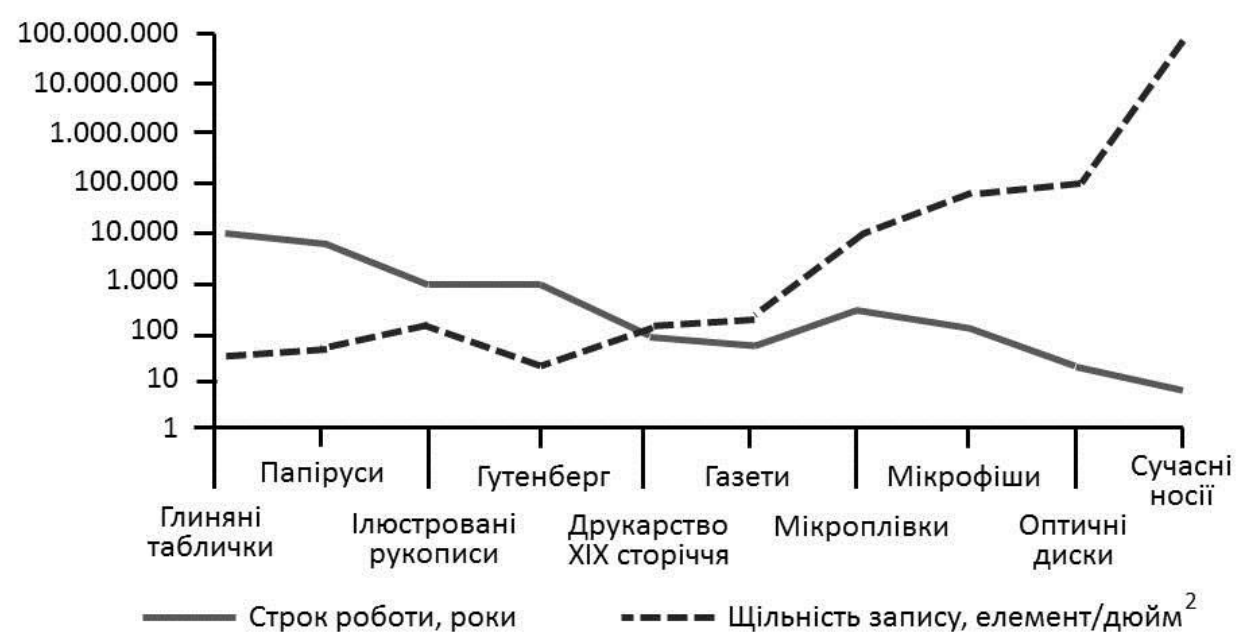

Щільність запису інформації та терміни зберігання інформації на різних носіях [7]

Важливим критерієм для визначення ефективності систем зберігання даних $\epsilon$ середня тривалість життя цифрових носіїв. Вибір носія з довготривалим строком зберігання даних для архівування цифрового контенту впливає не тільки на ціни, але і також на довгострокову безпеку об’єктів. Типові цифрові носії інформації мають очікувану тривалість життя від 3 до 10 років, при цьому реальний термін пошкодження інформаційної структури неможливо передбачити. Недовга тривалість життя носіїв, в поєднанні з неефективними та часозатратними процедурами резервного копіювання можуть призвести до втрати цифрового контенту, який підлягає довготривалому зберіганню. Третій критерій, який включає в себе термін служби носія інформації і пов'язані з цим витрати на цифрове збереження - це строки міграції даних. Кожен цифровий носій і будь-яка цифрова система має обмежений термін служби. 3 метою суттєвого збільшення строків збереження цифрових об’єктів, більшість цифрових носіїв інформації повинні бути поновлені, або інформація з них має регулярно переноситися на інші носії. Вартість переходу від одного покоління носіїв до іншого, або з одного виду носіїв на інший тип може становити значну проблему. Міграція буде включати вартість нових носіїв та нових систем, але вона повинна також включати витрати на персонал управління заміною і процесом перевірки, для того щоб переконатися, що в процесі переходу не спостерігається втрата данних або деградації носіїв [1]. Найбільш гостро питання довготермінового зберігання інформації стоїть для архівних фондів. На сьогодні, через відсутність наявних електронних носіїв, які б гарантували зберігання інформації більше ніж 100 років, перехід з аналогового подання даних (паперові документи) до цифрового є практично неможливим [3]. На жаль, сучасні носії даних не здатні забезпечити довгострокове зберігання даних. Пожежею у вежахблизнюках (Нью-Йорк, 11.09.2001р.) було знищено абсолютно всі цифрові носії. У цьому випадку варто згадати про глиняні таблички шумерів, які в шостому столітті до нашої ери витримали пожежу в бібліотеці Ашшурбаніпала та збереглися до нашого часу [32]. 
Альтернативною технологією довготермінового зберігання даних може бути використання носіїв з тривалим гарантованим строком експлуатації, iї перевага полягає в тому, що суттєво зменшуються витрати на зберігання даних за рахунок збільшення періоду міграції даних [1,32].

\section{Потенційні можливості оптичних носіїв інформації Амя забезпечення довготермінового зберігання даних}

Протягом більше 35 років оптичні диски використовуються як архіви для тривалого зберігання найважливішої науково-технічної інформації, патентної і технічної документації, медичних і юридичних документів, рентгенівських знімків тощо. Зараз основною областю використання оптичних дисків $є$ архівація даних.

Успішне використання оптичних дисків для довготермінового зберігання даних базується на основі можливостей і характеристик оптичного запису. Оптичні носії для довготермінового зберігання даних мають суттєві переваги порівняно з іншими технологіями зберігання даних, а саме:

1) запис інформації на оптичні диски є безконтактним, що виключає пошкодження поверхні носія. Такий запис даних має істотну перевагу, коли необхідно забезпечити довготермінове зберігання даних. Відносна простота способу відтворення означає, що майбутні оптичні системи відтворення легко можуть бути адаптовані в міру необхідності, щоб прочитати дані, які постійно зберігаються на оптичних дисках [8];

2) подання інформації на поверхні оптичних носіїв інформації у вигляді мікрорельєфу структур дозволяє зчитувати записану інформацію за допомогою різних методів. Записані зображення можуть бути проаналізовані візуально з використанням оптичних приладів;

3) для виготовлення оптичних носіїв можуть бути використані високостабільні матеріали, зміни властивостей яких відбуваються при температурі вище $2000{ }^{\circ} \mathrm{C}$;

4) відтворення даних з оптичних дисків не вимагає спеціального програмного забезпечення;

5) запис даних на оптичні диски здійснюється у форматах, які забезпечують сумісність записаних дисків різних типів;

6) пристрої відтворення інформації з оптичних дисків, створені з метою забезпечення зворотної сумісності, яка була реалізованою для приводів «Blu-Ray Disc», що зчитують носії у форматі CD та DVD;

7) характеристики оптичних дисків створюють можливості для забезпечення високої надійності довготермінового зберігання даних у широкому діапазоні температур і вологості. Компакт-диски зберігають записану інформацію, як правило, довше, ніж інші цифрові носії. Багаторічний досвід використання компакт-дисків довів, що їхнє використання $є$ ідеальним методом для архівації даних, тексту та зображень у цифровій формі. Дослідження довготермінового зберігання даних на компакт-дисках показали, що нікелеві штампи, які використовуються для копіювання компакт-дисків, можуть забезпечити довготривале зберігання даних $[9,10]$.

Незважаючи на невисоку швидкість запису-відтворення, оптичні диски досить ідеально підходять для архівування важливих даних і вони зберігають сильні 
позиції в архівній справі [11]. Як правило, виробники оптичних носіїв WORM прогнозують п'ятирічний строк придатності для чистих дисків і 20-30 років життя після запису. Ці строки очікуваної тривалості життя базуються на результатах випробувань носіїв різних виробників [12]. Використання оптичних дисків WORM являє собою певний ризик, хоча їхнє використання поширено особливо серед малих архівних установ. Розробка оптичних дисків для довготермінового зберігання даних була предметом інтенсивних досліджень в останні роки.

\section{Аналіз методів піАвищення термінів зберігання інформації на оптичних носіях 3 пластиковими піАкмадками}

Існуючі оптичні диски не можуть забезпечити необхідний рівень надійності і час збереження даних через низьку стабільність полікарбонатної підкладки [13]. Металевий відбивальний шар компакт-диска характеризується слабкою адгезією до підкладки з полікарбонату, що призводить до швидкого розшарування носія під час використання, особливо, при раптових змінах температури. Диски типу WORM та RW непридатні для архівного зберігання даних через те, що в їхньому інформаційному шарі використовуються для запису даних нестабільні органічні барвники (ціаніни, фталоціаніни і азобарвники) [11]. Для збільшення довговічності оптичних носіїв 3 пластиковими підкладками було запропоновано та розроблено багато технічних рішень. Розроблялися технології підвищення строків зберігання даних на оптичних носіях різних типів. Головним напрямком підвищення надійності зберігання даних на оптичних носіях з одноразовим записом була розробка спеціальних реєструвальних середовищ. Хоча органічні барвники успішно використовувалися для запису даних на оптичних дисках, в останні роки також широко розглядаються для запису неорганічні матеріали [14]. Лазерні написи на скляних неорганічних матеріалах можуть витримувати температуру до $1000^{\circ} \mathrm{C}$ i в принципі підтримувати стабільність даних і можливість їхнього відтворення до тисячі років [15]. Як один із матеріалів, які на даний час широко використовуються, є неорганічний матеріал, який включає в себе оксид паладію (Pd) [14]. Під дією сфокусованого лазерного випромінювання змінюється пропускання неорганічного реєструвального шару, який також включає в себе оксид Pd [14]. Крім того, використовується для запису неорганічний шар, який включає в себе оксиди 3 індію та олова [14]. У професійних оптичних дисках UDO, що призначені для довготермінового зберігання даних, використовують технологію запису на незворотних фазових переходах у неорганічних матеріалах, яка може забезпечити строк зберігання даних понад 50 років. Для того щоб захистити UDO-носії від фізичних ушкоджень і забруднень (пилу, відбитків пальців і т.д.), диск розміщено в міцному стандартному ISO 5,25-дюймовому картриджі [16]. Уже в перших розробках оптичних дисків WORM намагалися реалізувати технологію довготермінового зберігання даних [17]. Частина технічних рішень, а саме виготовлення підкладок 3 високостабільних матеріалів, здійснення запису даних у одношаровому реєструвальному середовищі з високостабільного матеріалу, знайшли використання у подальших розробках носіїв інформації довготермінового зберігання даних. Довговічність перших оптичних дисків складала 20-30 років завдяки змінам характеристик реєструвальних середовищ з халькогенідного скла і органічних барвників [18]. 
Альтернативний спосіб довготермінового зберігання даних на оптичних носіях передбачає використання одного шару з високим коефіцієнтом відбиття, на якому робиться запис, він також повинен мати високу адгезію до матеріалу підкладки [17]. Найбільший строк зберігання даних прогнозується на оптичних носіях з металокерамічним реєструвальним середовищем (фірмова назва М-диски). Використання термочутливого шару з високим коефіцієнтом відбиття дозволило не використовувати у М-дисках світловідбиваючі шари, що стало однією зі складових значного підвищення гарантованого строку зберігання даних [19]. Очікувана довговічність М-дисків складає понад тисячу років при температурі зберігання $25^{\circ} \mathrm{C}$ і відносній вологості оточуючого середовища 50 \%, однак уже при температурі $40{ }^{\circ} \mathrm{C}$ і відносній волості $70 \%$ очікувана довговічність складає 53 роки [19]. Національний інститут стандартів і технології (NIST) CША визначив термін збереження для М-диска в 1000 років (буква М у назві означає Millenium, тобто тисячоліття), полікарбонат витримує сильні перепади температур лише протягом короткого проміжку часу [20]. Технологія виготовлення компакт-дисків, яка базується на використанні пластикових підкладок з рельєфними направляючими доріжками, забезпечує технологічність виготовлення носіїв і можливість зчитування даних на порівняно простих пристроях. Така технологія забезпечує можливість масового виготовлення дешевих носіїв інформації різних типів, проте не може бути використана для виготовлення носіїв довготермінового зберігання даних через невисоку стабільність матеріалів, що застосовуються при виготовленні компактдисків усіх типів. Спроби використання компакт-дисків для організації довготермінового зберігання даних показали недостатню надійність.

\section{Створення оптичних носіїв Аовготермінового зберігання інформації на основі високостабільних матеріамів}

Проблема довготермінового зберігання даних вирішується створенням спеціальних носіїв інформації з оптичним зчитуванням, в яких використовується представлення даних у вигляді мікрорельєфних структур на поверхні високостабільних матеріалів (пропонується використовувати скляні [21], кварцеві $[22,23]$, кремнієві [24], нікелеві [25] або вольфрамові [26] підкладки). Носії довготермінового зберігання даних на основі високостабільних матеріалів повинні мати наступні властивості - високу стійкість до впливу підвищеної температури, водяного пару, електромагнітного випромінювання протягом тривалого періоду часу [27]. Технічні рішення, що пропонуються для створення технології довготермінового зберігання даних на оптичних носіях, засновані на використанні високостабільних матеріалів для підкладок носіїв інформації; так перші оптичні диски довготермінового зберігання мали у своїй основі підкладку із силікатного скла $[21,27]$.

На носіях з підкладками з високостабільних матеріалів використовують режим роботи ROM. Історичний досвід використання документів показав, що носії виготовлені з таких матеріалів зберігали записану інформацію протягом століть. Носії з таких матеріалів створені на теперішній час мають істотно більшу щільність і швидкість запису. Такі носії суттєво відрізняються від стандартних компакт-дисків унаслідок особливостей технології їхнього виготовлення, що заснована на застосуванні підкладок з нестабільного полікарбонату, який з часом змінює 
фізико-хімічні властивості, особливо в процесі багаторазових відтворювань записаної інформації [1]. Для довготермінового зберігання стратегічно важливої інформації запропоновано виготовляти підкладки оптичних носіїв із синтетичного сапфipy $[28,29]$. Пропонується використовувати оптичні носії з сапфіровими підкладками двох типів: сапфірові підкладки використовують як захисний шар високостабільного металевого реєструвального середовища (платинового) [28], у другій конструкції інформація записується у вигляді мікрорельєфних зображень на поверхні сапфірової підкладки. Залежно від обраної оптичної системи відтворення може відбуватись як через підкладку сапфірового носія, так і збоку записаних зображень $[29,30]$. Відтворення даних крізь прозору сапфірову підкладку забезпечує додатковий захист записаної інформації від забруднень, але вимагає розробки спеціальної оптичної системи компенсації аберацій, які виникають при проходженні сфокусованого оптичного випромінювання крізь анізотропну підкладку зі значним двопроменезаломленням [29].

Використання спеціальних оптичних носіїв дозволить значно збільшити час між проведенням міграції інформації для забезпечення гарантованого довготермінового зберігання даних. Нові розробки в області оптичних дисків для довготермінового зберігання даних відкривають нові можливості для більш повного задоволення мінливих потреб архівування даних з точки зору ємності та швидкості передачі даних [21-29].

\section{Анаміз технологій графічного представлення даних на носіях Аовготермінового зберігання}

Однією з ключових проблем при створенні носіїв довготермінового зберігання даних є вибір форми представлення даних, яка би дозволяла їх інтерпретувати та використовувати для отримання необхідної інформації. Такий вибір намагаються здійснити не тільки з технологічної точки зору, але і з використанням історичного досвіду застосування кодування інформації для передачі та збереження знань. Авторами роботи [7] пропонується запис інформації на носії довготермінового зберігання проводити шляхом розміщення на носії зменшених графічних або тестових зображень, які можуть зчитуватись оптичними системами. Перевагою такого способу подання інформації $є$ те, що наступне відтворення інформації не вимагає використання спеціальних пристроїв зчитування та відповідного програмного забезпечення. Необхідна роздільна здатність оптичної системи для зчитування визначається використаним зменшенням зображень під час запису інформації. Таке представлення даних використане на сапфірових і металевих дисках $[26,30,31]$.

На більшості розроблених носіїв довготермінового зберігання даних 3 підкладками з високостабільних матеріалів для запису інформації використовуються методи візуального кодування з використанням QR-кодів, які дозволяють відтворювати записану інформацію без використання спеціальних пристроїв зчитування, однак не забезпечують високої швидкості відтворення в автоматичному режимі [5-8]. Представлення даних на носіях довготермінового зберігання в QR-кодах і у вигляді мікрозображень здійснюється паралельно з використанням цифрового кодування, при якому може бути реалізована істотно більша щільність запису ін- 
формації [29, 32]. Запис інформації на носії, що виготовлені з високостабільних матеріалів, пропонується здійснювати у широковживаних форматах, які використовуються на компакт-дисках [33]. Такий вибір системи кодування базується на тому, що виготовлені та використовуються мільярди носіїв з таким методом представлення даних i, в разі необхідності, інформація може бути відтворена іншими методами, наприклад, методом тунельної скануючої мікроскопії. Базовий метод відтворення даних з таких носіїв передбачає використання стандартних пристроїв відтворення даних з компакт-дисків, у тому числі з оптичних дисків довготермінового зберігання даних, таких як М-диск DVD або Blu-ray. Однак висловлюються побоювання, що навіть такі коди у віддаленому майбутньому важко буде розшифрувати [34].

\section{Висновки}

1. Задача забезпечення довготермінового зберігання накопиченої інформації на всіх етапах розвитку людської цивілізації є однією з найважливіших, вирішення якої забезпечувало розвиток суспільства. Для збереження знань, накопичених людством, на всіх етапах розвитку суспільства використовувалися найбільш передові технології. На даний час обсяг інформації, яка підлягає тривалому зберіганню щорічно зростає практично експоненціально, що робить задачу довготермінового зберігання документів ще більш складною і актуальною. Збільшенню обсягу документів, які підлягають тривалому зберіганню сприяє те, що все більша кількість типів документів визнається такими, що підлягають тривалому зберіганню. Довготривалому зберіганню обов'язково підлягає науково-технічна, медикобіологічна та генетична інформації, об’єкти національної культурної спадщини, стратегічно важлива інформація.

2. Використання у системах довготермінового зберігання інформація цифрових носіїв зі строками зберігання даних 5-10 років вимагає проведення постійного перезапису даних на нові носії, що суттєво збільшує вартість зберігання даних і зменшує надійність їхнього зберігання.

3. Технологія виготовлення компакт-дисків заснована на використанні пластикових підкладок з рельєфними направляючими доріжками, що забезпечує технологічність виготовлення носіїв і можливість зчитування даних на порівняно простих пристроях. Така технологія забезпечує можливість масового виготовлення дешевих носіїв інформації різних типів, проте не може бути використана для виготовлення носіїв довготермінового зберігання даних через невисоку стабільність матеріалів, що застосовуються при виготовленні компакт-дисків усіх типів. Спроби використання компакт-дисків для організації довготермінового зберігання даних показали недостатню надійність і довготривалість зберігання даних.

4. Перевага носіїв з оптичним зчитуванням виготовлених з високостабільних матеріалів і М-дисків полягає в тому, що вони не вимагають оновлення записаної інформації або міграції даних, що значно зменшує вартість зберігання даних. Довготривале зберігання інформації може бути забезпечене на спеціальних оптичних носіях інформації, виготовлених з високостабільних матеріалів, запис даних на які зроблено у форматах стандартних компакт-дисків. 


\section{Подяки}

Автори висловлюють глибоку подяку співробітникам Інституту проблем реєстрації інформації НАН України за допомогу у виготовленні зразків носіїв інформації, здійсненні запису інформації та їхньої подальшої обробки, а також за плідне обговорення результатів досліджень.

1. Erickson C.L., Lunt B.M. Alternatives for Long-Term Storage Of Digital Information. URL: https://sites.lib.byu.edu/digitalpreservation/wp-content/uploads/sites/21/2015/11/iPres_poster_2015 _resubmit2-Erickson_Lunt.pdf

2. Hedstrom M. Digital preservation: a time bomb for Digital Libraries. URL: https://pdfs.semanticscholar.org/1f78/ff102bc627e675a8df7db2d996 c69faad8cd.pdf

3. Шаплбаров И. Перевод архивов в электронный вид - актуальная, но пока неразрешимая задача. PC WEEK/RE. 2015. № 6. C. 3-4.

4. Steffen W. Schilke Long-term archiving of digital data on microfilm. Int. J. Electronic Governance. 2010. Vol. 3. N 3. P. 237-253.

5. Alternative Storage Technologies. URL: http://docplayer.net/3509007-Alternative-storagetechnologies.html

6. Ефимов Д.А. Скрижали 21 века - применение металлических носителей для сверхдолгого хранения оцифрованных библиотек. Библиотеки и информационные ресурсы в современном мире науки, культуры, образования и бизнеса. XVII Международная конференция «Крым 2010», 5-13 июня 2010 г.

7. The Preservation of Records,Knowledge and Memory (RK\&M) Across Generations: Improving Our Understanding Workshop Proceedings 12-13 September 2012NEA Headquarters, Issy-lesMoulineaux (France). URL: https://www.oecd-nea.org/rwm/reports/.../rwm-r2013-3.pdf

8. Система зчитування даних з оптичного носія: пат. 104961 Україна: МПК G11 В7/24. Опубл: 25.03.2014.

9. Petrov V.V., Kryuchyn A.A., Shanoylo S.M., Kryuchyna L.I., Kossko I.O. The MetalCarriers for Long-Term Storage of the Information: Exec. Ed. Dodonov O.G. (NAS of Ukraine, Institute for Information Recording, (Naukova dumka, Kiev, 2005) [in Ukrainian].

10. Петров В.В., Крючин А.А., Шанойло С.М. Горьов І.В., Морозов С.М., Березін Б.О. Оптичні носії для довготермінового зберігання інформації. Страховий фонд документації. 2016. № 1(20). С. 44-55.

11. Jacobi J.L. Hard-core data preservation: The best media and methods for archiving your data. PCWorld. FEB 29, 2016. URL: http://www.pcworld.com/article/2984597/storage/hard-core-datapreservation-the-best-media-and-methods-for-archiving-your-data.html.

12. NARA/Long-Term Usability of Optical Media. URL: http://cool.conservation-us.org/ bytopic/ electronic-records/electronic-storage-media/critiss.html

13. Nikles D.E., Wiest J.M. Accelerated aging studies and the prediction of the archival lifetime of optical disc media. Proc. SPIE. 1999. 3806. P. 30-36.

14. Optical information recording medium: patent 8,865,286 USA: MКИG11В7/24. Т. Hiroshi, M. Takeshi; заявл. 23.01.2012; опубл.21.10.2014.

15. Min G., Xiangping L., Yaoyu C. Optical storage arrays: a perspective for future big data storage. Light: Science \& Applications (2014)3, e177; DOI :10.1038/1sa.2014.58. 
16. Plasmon News. First Real-Time Tests Help Determine Security of Data Stored on WORD Media. URL: http://www.plasmon.com.

17. Петров В.В. Крючин А.А., Токарь А.П. и др. Оптико-механические запоминающие устройства. Киев: Наук. думка, 1992. 152 с. ISBN 5-12-002345-2.

18. Petrov V.V., Kryuchin A.A., Gorbov I.V., Kossko I.O., Kostyukevych S.O. Analysis of properties of optical carriers after long-term storage. Semiconductor Physics, Quantum Electronics and Optoelectronics. 2009. 12(4). P. 399-402.

19. Summary Report by ISO/IEC 10995 Test Program Performed by Millenniata on M-DISCTM DVD. URL: http://www.mdisc.com/uploads/M-DISC_1sheet_Test_Summary.pdf

20. Изучаем накопители для длительного хранения данных. URL: http://ichip.ru/izuchaemnakopiteli-dlya-dlitelnogo-hraneniya-dannih.html

21. Syylex permanent storage. Longevity tests. URL: http://www.syylex.com/longevity_tests.html

22. Kazansky P., Cerkauskaite A., Beresna M., Drevinskas R., Patel A., Zhang J., Gecevicius M. Eternal 5D data storage via ultrafast-laser writing in glass. SPIE Newsroom. 11 March 2016. DOI: $10.1117 / 2.1201603 .006365$

23. Successful read/write of digital data in fused silica glass with a recording density equivalent to Blu-ray. URL: http://www.hitachi.com/New/cnews/month/2014/10/141020a.pdf

24. Wafer-scale image archiving and receiving system: patent 8155427 USA: МКИ, G06F12/00. Ajay Pasupuleti; заявл. 14.12. 2007; опубл. 10.04.2012.

25. Heminger A.R., Robertson S.B. Digital Rosetta stone: A conceptual model for maintaining long-term access to digital documents. J. Management Inf. Sys. 2005. 21. P. 11-35.

26. De Vries J., Schellenberg D., Abelmann L. [et al.]. Towards Gigayear Storage Using a SiliconNitride/Tungsten Based Medium. URL: https://arxiv.org/abs/1310.2961

27. Norsam Technologies, Inc. Norsam Technologies, Inc. Ultra-High DensityAnalog and Digital Data Storage.URL: www.thic.org/pdf/Apr98/norsam.jbishop.pdf

28. Object provided with a graphics element transferred onto a supportwafer and method of producing such an object: пат. WO 2009/092794 A2. A.-M. Rey (Fr), J.-F. Clerc(Fr), A. Soubie (Fr), L. Vandroux (Fr); заявл. 23.01.2009; опубл. 24.09.2009.

29. Petrov V.V., Semynozhenko V.P. Puzikov V.M., Kryuchyn A.A., Lapchuk A.S., Morozov Ye.M., Borodin Y.O., Shyhovets O.V., Shanoylo S.M. Method of aberration compensation in sapphire optical discs for the long term data storage. Functional Materials. 2014. Vol. 21. No 1. P. 105-111.

30. Rey A., Benzakour $F$. Preserve your most precious me-mories for thousands of years. Fahrenheit 2451 - Preserve Your Data in a Sapphire Disk. URL: http://icrowdnewswire.com/2015/ 06/30/fahrenheit-2451-preserve-your-data-in-a-sapphire-disk-preserve-your-most-precious-memories-forthousands-of-years-the-only-storage-medium-that-resists-fire-water-and-time. July 14, 2015.

31. New storage disc that secures data for 2.000 years. URL: http://www.abovetopsecret.com/ forum/thread855634/pg1

32. Петров В.В., Семиноженко В.П. Новітня технологія довготермінового зберігання інформації на сапфірових оптичних дисках. Вісн. НАН України. 2014. № 4. С. 24-32.

33. Petrov V.V., Kryuchyn A.A., Shanoylo S.M., Kossko I.O., Kravets' V.G. Methods of solving the problem of long-term information storage recorded in a digital form. Rep. of the Nat. Acad. Sci. of Ukraine. 2003. N 4. P. 52-58 [in Ukrainian].

34. Lunt B.M. How long is long-term data storage? Archiving 2011 Final Program and Proceedings. URL: http://www.imaging.org/site/PDFS/Reporter/Articles/REP26_3_4_ARCH2011_Lunt.pdf 